\title{
PENGUATAN GURU PAK UNTUK PENDIDIKAN KARAKTER: MELIHAT KONTRIBUSI SERI SELAMAT
}

\author{
Binsen S. Sidjabat \\ Sekolah Tinggi Alkitab Tiranus \\ Jl. Raya Cihanjuang No.11, Cihanjuang, Parongpong, Kabupaten Bandung Barat, Jawa Barat 40559 \\ email: bssidjabat11@yahoo.com
}

\begin{abstract}
Abstrak: Binsen S. Sidjabat, Penguatan Guru PAK Untuk Pendidikan Karakter: Melihat Kontribusi Seri Selamat. Artikel ini membahas kontribusi Seri Selamat karya Andar Ismail untuk meluaskan pemahaman guru PAK di sekolah terkait pendidikan karakter. Delapan belas tema karakter bangsa yang diajarkan perlu guru kepada siswa di sekolah dapat diterangi oleh beragam topik atau judul dalam Seri Selamat. Dengan mempelajari topik atau judul yang diangkat oleh tulisan ini dari studi Seri Selamat, diharapkan guru PAK yang mempelajari, akan memperoleh pemikiran yang menguatkan dan memperkaya pelaksanaan tugasnya dalam pendidikan iman terintegrasi dengan pembentukan karakter siswa. Pembina warga jemaat di gereja pun dapat beroleh manfaat dari hasil studi ini.
\end{abstract}

Kata kunci: pendidikan karakter, PAK, guru, Seri Selamat.

\begin{abstract}
Binsen S. Sidjabat, Strengthening Teacher Christian Education for Character Education: Seeing Contributions Selamat Series. This article describes significance of Andar Ismail's Selamat Series for teachers of Christian religious education in school context of Indonesia to develop character formation. There are eighteen aspects of national values that can be used by teachers as framework in helping students to learn Christian values and character. Selected chapters and writings from the Selamat Series can contribute the understanding of Christian teachers on the eighteen national values. Christian nurture in the church can also be benefitted by this research.
\end{abstract}

Key words: character education, Christian Religious Education, teacher, Selamat Series.

\section{PENDAHULUAN}

Meresponi pemerosotan budi pekerti manusia secara global dan lokal, pentingnya pendidikan karakter di sekolah sudah ditekankan oleh pemerintah sejak tahun 2010 yang lalu. Hal tersebut ditegaskan dalam Peraturan Pemerintah R.I Nomor 17 Tahun 2010 Tentang Pengelolaan dan Penyelanggaraan Pendidikan, Bab III, tentang fungsi dan tujuan pendidikan anak usia dini; pendidikan dasar; pendidikan menengah; dan pendidikan tinggi. Perkara itu kemudian dijabarkan oleh Kebijakan Nasional Pembangunan Karakter Bangsa Tahun 2010-2025 (Pemerintah RI, 2010), Bahan Pelatihan Pengembangan Pendidikan Budaya dan Karakter Bangsa (Kementerian Pendidikan Nasional (2010) dan Pedoman Pelaksaan Pendidikan Karakter (Kementerian Pendidikan Nasional, 2011). Baru-baru ini Pemerintah menegaskan kembali pelaksanaan pendidikan karakter bangsa itu melalui Peraturan Presiden No. 87 Tahun
2017, selanjutnya diikuti oleh Permendikbud Nomor 20 Tahun 2018. Sebelumnya, cukup banyak tulisan mengenai pendekatan, metode, model dan strategi pendidikan karakter diungkapkan oleh pemerhati dan pakar pendidikan, mengenai implementasi kebijakan itu dalam konteks sekolah melalui mata pelajaran khusus (intrakurikuler), dan atau terintegrasi dengan mata pelajaran dan kegiatan pendidikan lainnya (kokurikuler dan ekstra kurikuler). (Lihat Farida, 2012, pp. 445-452; Susanti, 2013, pp. 480-487; Lie, 2014, pp. 73-94; Dhiu \&Bate, 2017, pp. 172176; Aeni, 2014, pp. 50-58; Akbar, Samawi, Arafiq, \&Hidayah, 2014, pp. 138-151).

Pendidikan Agama Kristen (PAK) juga meresponi pendidikan karakter itu. Oleh sebab itu berkembang beragam tulisan tentang bagaimana PAK di sekolah sepatutnya mengakomodasi pendidikan karakter. Dengan demikian berkembangkan gagasan PAK berbasis karakter (Rifai, 2018; Simorangkir, 
2013, pp. 39-44; Hartono, 2014, pp. 62-69). Nuhamara (2018, pp. 93-115) menekankan bahwa PAK di sekolah bukan hanya menuntun siswa memahami iman Kristen dalam tataran pengetahuan, tetapi juga bagaimana mereka mengalami transformasi spiritual dan karakter. Menurutnya, iman Kristen yang diajarkan dalam PAK menuntut aplikasinya dalam perubahan nilai hidup dan budi pekerti.

Menyusun materi kurikulum untuk membantu siswa belajar karakter dari sudut iman Kristen bukanlah pekerjaan mudah bagi guru PAK. Prinsipprinsip dan praktik pengembangan kurikulum patut dipahami (Sanjaya, 2008; Pazmino, 2008; Colson \& Rigdon, 1981; "Kurikulum Berbasis Kompetensi (KBK) Pendidikan Agama Kristen", 2003; Tim Pengembangan MKDP Kurikulum dan Pembelajaran, 2011). Dapat diduga bahwa para guru tentunya sudah memahami bahwa tema pelajaran PAK di sekolah ialah "Allah Tritunggal dan nilai-nilai kristiani." Lazimnya guru PAK patut mengerti standar kompetensi dan kompetensi dasar pelajaran PAK untuk tingkat Sekolah Dasar dan Sekolah Menengah. Namun, guru PAK masih membutuhkan pelatihan dan bimbingan bagaimana membangun dan mengembangkanmateri kurikulum pendidikan karakter berdasarkan kerangka pendidikan karakter bangsa yang menekankan delapan belas nilai hidup meliputi: religius, jujur, toleran, disiplin, bekerja keras, kreatif, mandiri, demokratis, rasa ingin tahu, semangat kebangsaan, cinta tanah air, menghargai prestasi, komunikatif, cinta damai, gemar membaca, peduli lingkungan, peduli sosial dan bertanggung jawab. (Permendikbud R.I Nomor 20 Tahun 2018, Pasal 3). Hal tersebut di atas sebelumnya sudah dikemukakan dalam Bahan Pelatihan Pengembangan Pendidikan Budaya dan Karakter Bangsa (Kementerian Pendidikan Nasional (2010) dan Pedoman Pelaksaan Pendidikan Karakter (Kementerian Pendidikan Nasional, 2011).

Seri Selamat adalah buku-buku renungan karya Andar Ismail yang ditulis sejak tahun 1981 menjadi materi belajar bagi warga jemaat dewasa, agar memahami iman Kristen kemudian diterapkan dalam kehidupan sehari-hari. Buku-buku renungan ditulis bukan secara akademik melainkan secara popular, sehingga diharapkan dapat membantu warga jemaat dengan mudah memahami iman Kristen, lalu membangkitkan perenungan yang menyentuh kognisi dan afeksi mereka. Selain memuat uraian hasil studi Alkitab dan pengetahuan, banyak tulisan di dalam Seri Selamat menyajikan pengajaran moral dan karakter atau watak. Sidjabat (2018, pp. 175-183) mengemukakan bahwa pembaca Seri Selamat menilai bahwa karya Andar Ismail itu bermanfaat bagi kehidupan pribadi dan pelayanan gerejawi mereka. Oleh karena itu, penulis makalah ini memandang bahwa tulisan-tulisan di dalam Seri Selamat dapat berguna secara langsung bagi guru PAK sebagai warga jemaat dewasa, dalam merencanakan dan mengelola kegiatan belajar agama Kristen berbasis karakter. Guru PAK yang mengelola pembinaan warga jemaat anak, remaja, pemuda dan orang dewasa pun dapat beroleh masukan berharga dari Seri Selamat khususnya terkait pendidikan nilai hidup dan karakter.

Guru PAK tampaknya dapat terbantu untuk membahas karakter dari iman Kristen oleh buku pegangan yang tersedia seperti Cermin Remaja, Suluh Siswa dan karya Butarbutar dan Bessie (2013). Dalam pengamatan penulis tema karakter yang dibahas sumber-sumber itu terlihat masih terbatas. $\mathrm{Pa}$ dahal, sebagaimana disinggung di atas ada delapan belas nilai dan karakter bangsa yang patut dipelajari murid dalam konteks sekolah. Mengingat guru PAK membutuhkan pandangan Kristen tentang topik-topik karakter yang lebih luas, maka makalah ini memandang bahwa tulisan-tulisan di dalam Seri Selamat dapat bermanfaat dan sebab itu patut ditelusuri.

Masalah yang menjadi perhatian tulisan ini ialah belum adanya sumber pengetahuan bagi guru PAK dan pembina warga jemaat, tentang delapan belas nilai dan karakter bangsa berdasarkan perspektif iman Kristen, yang patut dipercakapkan bersama anak didik. Oleh sebab itu, tulisan ini bertujuan menyediakan informasi bagi guru PAK, yang tentunya diharapkan berguna bagi pembina warga jemaat, me- 
ngenai penguatan pendidikan nilai dan karakter, bertolak dari telaah Seri Selamat karya Andar Ismail.

\section{METODE}

Dalam rangka mendukung guru PAK sebagai pendidik karakter maka tulisan ini mengemukakan apa yang mungkin dapat dipelajari dari Seri Selamat guna menguatkan pengembangan pendidikan karakter. Pertanyaan utama yang mengarahkan studi dan tulisan ini ialah "Apa kontribusi Seri Selamat dalam meningkatkan pelayanan guru PAK untuk mengembangkan pendidikan karakter dalam konteks sekolah?" Metode yang dipergunakan mewujudkan studi adalah penelitian dokumen hasil karya tokoh yang berotoritas dalam bidangnya, sebagai sumber primer. Dua puluh sembilan buku-buku renungan Seri Selamat merupakan sumber utama dalam studi, yang dianalisis secara cermat supaya hasilnya dipergunakan untuk mengkonstruksi pemahaman (Bnd. Booth, Colomb \& Williams, 1995, pp. 101-102).

Penelitian ini dapat dinyatakan bersifat kualitatif, tekstual, konseptual dan konstruktif (Warren \& Karner, 2015, pp. 169-180), dalam pemikiran Cresswell (2013, pp. 70-76) studi ini dilakukan dengan pendekatan naratif. Jadi, penelitian ini merupakan sebuah penelitian kualitatif konseptual yang hasil analisisnya disajikan secara naratif, bukan berupa data kuatitatif. Penelitian ini tidak menggunakan meta analisis melainkan menggunakan analisis tekstual yang akhirnya disajikan secara naratif.

\section{HASIL DAN PEMBAHASAN}

Uraian di bawah ini memuat dua hasil temuan dan pembahasan. Pertama, tentang pengertian karakter, pendidikan karakter termasuk pendekatannya menurut pendidikan nasional dan seorang pendidik Kristen. Kedua, mengenai riwayat singkat dan karakteristik Seri Selamat, serta penyingkapan beragam topik pengajaran yang berguna menguatkan guru PAK memahami delapan belas nilai dan karakter bangsa.

\section{Karakter dan Pendidikan Karakter}

Scott B. Rae (2009) menuliskancharacter is the tendency of a person to act in predictable ways over time (p. 17). Karakter merupakan sikap dan perilaku yang dipertimbangkan orang dalam dalam bergam pengambilan keputusan. Sebelum menerima seorang pelamar untuk bekerja, pimpinan perushaan akan mempelajari apakah yang bersangkutan dapat dipercaya atau tidak, jujur atau licik, rajin atau malas, hemat atau boros. Menurut Sidjabat (2008, 2011, 2011), karakter adalah sifat khas seseorang yang nyata dalam sikap, perasaan, pemikiran dan perbuatannya. Karakter terbentuk melalui hasil pengamatan, peniruan, identifikasi individu dalam keluarga, lingkungan sosial terdekat dan lingkungan sosial lebih luas mencakup masyarakat etnisnya. Karakter juga terbentuk melalui hasil belajar terintegrasi dengan faktor genetik individu serta intervensi ilahi, dari Tuhan atau dari roh-roh jahat atau Iblis.

Hasil belajar itu menumbuhkan dua jenis karakter yakni karakter baik yang kaya dengan sifatsifat luhur atau kebajikan dan menjadi tenaga pendorong untuk keberhasilan, yang sering disebut virtues. Perangai sebaliknya adalah karakter buruk diwarnai tabiat atau kebiasaan jelek bahkan jahat, yang lazim dinamakan vices. Tepat sekali Alasdair MacIntyre (1984) mendefinisikan virtuesebagai an acquired human quality the possession and exercise of which tends to enable us to achieve those goods which are internal to practices and the lack of which effectively prevents us from achieveing any such goods (p. 191). Jadi, karakter virtues adalah sifat-sifat yang membuat kita mengejar dan melakukan kebaikan serta bergairah atau bersemangat (virtuous). Oleh karena itu, ketiadaan virtues menuntun kita melakukan hal-hal yang berlawanan.

Mengubah vices menjadi virtues membutuhkan upaya manusiawi yang kompleks dan intervensi Allah yang penuh anugerah (Kej. 1:26-27; Ef. 1:10; 2 Kor 3:17-18; 5:17). Pieter Vos menyatakan bahwa pembentukan karakter bersifat komplek dimana banyak faktor menentukan saling terkait (2018, pp. 1728). Dalam pemahaman Greenman \& Kalantzis 
(2010) dan Issler (2012), ketika Yesus Kristus menjamah dan Roh Kudus mendiami serta menuntun hidup seseorang maka di dalam dirinya bertumbuh perangai baru, yang tidak lain adalah sifa-sifat Kristus (bd. Mat. 5:3-10; 9:36; 11:28-30), dan akhlak mulia hasil karya Roh Kudus (bd. Gal. 5:16-18; 22-23). Ditekankan oleh Dennis (2005) bahwa pembentukan dan pengembangan karakter dapat dikembangkan berdasarkan studi nilai hidup dan karakter Kristus sebagaimana diungkapkan kitab-kitab Injil. Meskipun terbatas, pembentukankarakter dalam pendidikan formal secara umum, patut dipandang perlu sebagai salah satu pengalaman bagi transformasi hidup manusia.

Pemerosotan moral dan sikap yang bertentangan dengan nilai-nilai hidup bangsa berdasarkan agama dan Pancasila sebagaimana nyata di tengah masyarakat, telah memotivasi pemerintah melalui departemen pendidikan nasional, menggiatkan pelaksanaan pendidikan karakter melalui pendidikan formal. Dalam salah satu pedoman dan kebijakan pemerintah dinyatakan bahwa pendidikan karakter yang dikembangkan di sekolah merupakan integrasi dari empat kegiatan yang disebut olah hati, olah pikir, olah raga dan kinestetik, dan olah rasa dan karsa (Kementerian Pendidikan Nasional, 2010, pp. 9-10).

Dalam Pedoman Pelaksanaan Pendidikan Karakter (Kemendiknas, 2011) dikemukakan pula bahwa dengan kegiatan olah hati guru menuntun peserta didik beriman dan bertakwa, jujur, amanah, adil, bertanggung jawab, berempati, berani mengambil resiko, pantang menyerah, rela berkorban, dan berjiwa patriotik. Melalui kegiatan olah pikir, guru membimbing peserta didik berkarakter cerdas, kritis, kreatif, inovatif, ingin tahu, berpikir terbuka, produktif, berorientasi Ipteks, dan reflektif. Dengan kegiatan olah raga guru membangun perangai bersih dan sehat, disiplin, sportif, tangguh, andal, berdaya tahan, bersahabat, kooperatif, determinatif, kompetitif, ceria, dangigih, pada diri peserta didik. Akhirnya, dengan kegiatan olah rasa dan karsa guru menumbuhkan sifat dan kebiasaan ramah, saling menghargai, toleran, peduli, suka menolong, gotong royong, nasio- nalis, kosmopolit, mengutamakan kepentingan umum, bangga menggunakan bahasa dan produk Indonesia, dinamis, kerja keras, dan beretos kerja dalam diri peserta didik. Dalam Peraturan Presiden Republik Indonesia Nomor 87 Tahun 2017 Tentang Penguatan Pendidikan Karakter ditegaskan, "Penguatan Pendidikan Karakter yang selanjutnya disingkat PPK adalah gerakan pendidikan untuk memperkuat karakter peserta didik melalui harmonisasi olah hati, olah rasa, olah pikir, dan olah raga, dengan pelibatan dan kerjasama antara satuan pendidikan, keluarga, dan masyarakat sebagai bagian dari Gerakan Nasional Revolusi Mental (GNRM)" (Pasal 1.1).

Tampak bahwa terbuka lebar ruang bagi gereja dan lembaga gerejawi serta pendidikan Kristen untuk mereponsi pembentukan dan transformasi karakter sebagaimana diharapkan pendidikan nasional. Menuntun anak didik melalui PAK konteks sekolah dan jemaat agar mengalami perjumpaan pribadi dengan Yesus Kristus dan menikmati hidup bersama Roh Kudus, menjadikan pendekatan olah pikir, olah hati, olah rasa dan olah raga sebagaimana disinggung di atas, lebih efektif dan bermakna.

Pendidikan nasional menekankan bahwa penanaman nilai-nilai dan karakter bangsa patut dilaksanakan dengan pendekatan keteladanan, pembelajaran, pembudayaan dan penguatan. Selain itu, salah satu strategi pembelajaran yang harus digiatkan ialah mengintegrasikan pendidikan karakter ke dalam setiap mata pelajaran (PP No. 87/2017, Pasal 5, Pasal 6.1, dan Pasal 7). Dalam pengertian itulah guru PAK serta pembina warga jemaat, mempunyai peran penting untuk menuntun peserta didik mengembangkan karakter. Mengingat pendidikan karakter penting dikelola secara kreatif dan berkesinambungan sebagai ruang bagi Roh Allah berkarya dalam hidup anak didik (Dykstra, 2005), maka guru PAK juga patut memahami pendekatan dari perspetif Kristen.

Pakar teologi dan pendidikan warga jemaat, Wright (2010, pp. 257-284), mengusulkan sebuah pendekatan pendidikan karakter yang dinamainya model lima saluran, yakni: pertama, saluran Kitab Suci (scripture); kedua, saluran cerita-cerita di ma- 
syarakat dan konteks budaya (stories); ketiga, saluran contoh, model, atau teladan (examples); keempat, saluran komunitas pendukung (community); dan kelima, saluran praktik, perbuatan, tindakan konkrit (practices).

Secara sederhana, aplikasinya dapat dijelaskan sebagai berikut. Seandainya guru PAK mengajak murid belajar sebuah karakter, maka mereka dapat menempuh salah satu atau bahkan semua saluran tadi. Misalkan saja guru menuntun murid memahami nilai dan karakter jujur, disiplin dan tanggung jawab. Melalui saluran pertama, mereka mempelajari Alkitab terutama melihat ajaran dan teladan Yesus dalam Injil (scriptures). Melalui saluran kedua guru dan murid mempelajari cerita-cerita dalam masyarakat yang mengandung nilai jujur, disiplin dan bertanggung jawab (stories).

Melalui saluran ketiga, guru bersama murid mendiskusikan teladan hidup kontemporer yang memperlihatkan ketiga karakter tersebut (examples). Selanjutnya, melalui saluran keempat, guru dan murid merencanakan praktik kejujuran, disiplin dan tanggung jawab, selama satu bulan (practices). Akhirnya, melalui saluran kelima, guru dan murid berkomitmen saling mendoakan, saling mengingatkan dan saling mendukung dalam praktik kejujuran, disiplin dan tanggung jawab itu. Guru dan murid perlu berkomitmen membentuk dan memelihara kelompok pendukung (community) itu.

Pendekatan yang diusulkan Wright itu dapat memotivasi guru PAK, juga pembina warga jemaat, mengajarkan iman Kristen dan karakter dengan saluran-saluran variatif. Sebab, pada umumnya guru PAK hanya terfokus kepada studi Alkitab. Apabila guru tidak kreatif, peserta didiknya akan segera bosan. Oleh sebab itu jika sedikit lebih cerdas dan berani, guru PAK mula-mula dapat menyajikan ceritacerita budaya, kisah pengalaman hidup orang lain, refleksi pribadi, dan teladan tokoh-tokoh gereja. Jarang guru PAK merencanakan praktik yang dilakukan bersama murid, kemudian membahas pengalaman bersama itu. Belakangan ini berkembang pendekatan pendidikan karakter dengan sebutan teaching in Christian practices, yang diperkenalkan oleh Dykstra (2005) dan Bass (2010), kemudian dikembangkan oleh pakar pendidikan Kristen lainnya. Inti pendekatan ini ialah guru dan peserta didik menciptakan kegiatan, melakukan dalam kurun waktu tertentu, kemudian melakukan refleksi (Smith \& Smith, 2011).

\section{Menyingkap Penguatan Seri Selamat}

Penguatan pendidikan karakter mengandung arti penegasan dan peningkatan kegiatan yang sudah dan sedang dilaksanakan, supaya semakin efektif, kreatif dan berdampak. Untuk itu guru PAK membutuhkan bahan-bahan bacaan yang dapat menambah pengetahuan, meluaskan pemahaman, dan membangkitkan perenungan mengenai topik-topik karakter bangsa. Sebagaimana disinggung di atas, tidak mudah bagi guru memperoleh bahan-bahan bacaan yang kreatif di luar bentuk textbook yang sifatnya akademik, serta sekaligus berguna sebagai materi pembelajaran agama dan karakter.

Tulisan ini memandang bahwa Seri Selamat dapat memberi masukan berharga bagi guru. Alasannya, karya Andar Ismail itu memuat beragam tulisan kreatif hasil studi Alkitab, riwayat tokoh signifikan, cerita-cerita dalam budaya, contoh praktikpraktik karakter, dan cerita pergumulan dan keuntungan yang diperoleh komunitas ketika mempraktikkan nilai-nilai hidup Kristen. Menurut Sidjabat (2018) surat-surat yang berisi komentar pembaca Seri Selamat memberi indikasi bahwa tulisan-tulisan di dalamnya telah memberi kontribusi positif. Terkait alasan itu, patutlah terlebih dahulu dijelaskan riwayat singkat Seri Selamat dan kaitannya dengan pendidikan nilai hidup dan karakter. Selanjutnya, secara kategorial dikemukakan nilai dan karakter hasil telaah Seri Selamat.

\section{Riwayat dan Karakteristik Seri Selamat}

Buku-buku renungan Seri Selamat ditulis Andar Ismail (1940) sejak tahun 1981, dan dimaksudkan sebagai materi kurikulum pendidikan agama Kristen (PAK) warga jemaat dewasa. Dengan mem- 
baca buku-buku renungan yang kini (2018) berjumlah 29 judul, diharapkan orang dewasa dan warga lanjut usia mendapat topangan dalam menjalankan tugas dan tanggung jawab mereka di keluarga, tempat kerja, gereja dan di masyarakat (Sidjabat, 2018, pp. 56-58). Setiap judul Seri Selamat memuat 33 bab dikemas dengan beragam genra tulisan.

Sidjabat (2018) menjelaskan genra tulisan dalam Seri Selamat mencakup: analisis Alkitab, sosok Yesus, sosok-tokoh Alkitab, prosfenese, sejarah gereja/pekabaran Injil, tokoh Kristen masa dulu, tokoh Kristen masa kini, tokoh beragama lainnya yang terkait Kristen, cerita anak, cerita rakyat, novel, lagu, persilangan budaya dan Injil, ulasa buku, parodi, satire, kritik sosial, profense, surat pembaca, wawancara khayali, anekdot, kenangan masa kecil, dan curhat penulis. Andar mengaku angka 33 itu melambangkan hormat dan baktinya kepada Tuhan Yesus Kristus (Sidjabat, 2018, pp.3, 134-135).

Seri Selamat juga memuat beragam tulisan sebagai buah integrasi pemahaman Alkitab, teologi, pengetahuan sosial dan budaya, spiritualitas, pengalaman hidup, dan didaktik literatur serta keterampilan jurnalistik. Dapat dikatakan bahwa Seri Selamat adalah sebuah model pembelajaran yang mengajak orang dewasa memahami Alkitab dengan pendekatan literatur, yaitu buku-buku renungan yang ditulis secara populer sehingga warga jemaat awam (populi) mampu menangkap pesan. Andar Ismail berusaha memberi penjelasan duduk masalah topik yang dibahas agar menjadi pilihan pemikiran bagi pembaca.

Dikatakan pula bahwa Seri Selamat tidak berniat menggurui, mendikte orang dewasa tentang apa yang harus dilakukan. Pembaca dapat saja menerima atau sebaliknya menolak yang dikemukakan Andar Ismail. Yang penting, pembaca dapat memahami pikiran, pendapat, pergumulan, perasaan dan sikap pembuat tulisan (Sidjabat, 2018, pp. 135-141). Pendekatan Andar ini sebenarnya merupakan bentuk dari usulan para sarjana Alkitab dewasa ini, yaitu pentingnya mengajarkan Alkitab melalui budaya po- puler bahkan melalui seni (popular culture and arts) (Ronance dan Gray (Editor), 2007, pp. 241-324).

Secara ekplisit, Seri Selamat memperlihatkan pandangan Andar bahwa pendidikan karakter harus dilakukan sejak dini dalam keluarga. Dalam Ribut Rukun (Ismail, 1994, pp. 29-33) hal itu dinyatakan melalui "Menumbuhkan Sifat Watak Bertanggung Jawab." Dalam Panjang Umur (Ismail, 1995) perkara itu ditegaskan melalui doa bagi transformasi karakter dalam topik "Tuhan, Jadikan Saya Sebutir Ubi" (pp. 59-62), dan judul "Melucuti Hati" (pp. 137-140). Dalam Menabur (Ismail, 1997) tiga tulisan tentang keharusan pendidikan karakter konteks gereja dan sekolah, yakni "Tentang Li dan Arete" (pp. 22-24), "Kebiasaan Adalah Alam Kedua" (pp. 81-84), dan "Hidup Itu Belajar" (pp. 120-123).

Secara implisit pentingnya pendidikan karakter dikemukakan Andar Ismail dalam Berkembang (2003), melalui lima pemaparan yakni "Mengembangkan Watak" (pp. 53-55), "Pertimbangan Moral" (pp. 69-72), "Kecerdasan Emosional" (pp. 100-103), "Kecerdasan Spiritual" (pp. 104-107), dan "Perkembangan Kepribadian" (pp. 113-118). Sedangkan dalam dalam Mewaris (2005) hal itu dinyatakan melalui "Nilai-nilai Hidup. Bingung?" (pp. 69-72). Dalam Berjuang (2012) pendapat itu ditegaskan melalui "Akal Budi dan Akal Bulus" (pp. 79-82). Dalam Berpadu (2014) aspek itu dimuat oleh topik "Berpadu: Satu Tingkah Langkah" (pp. 1-4) dan “Aku Yang Terpadu” (pp. 112-115). Dalam Membarui (2017) pembenahan karakter dikemukakan melalui "Revolusi, Transformasi, atau Reformasi" (pp. 47) dan "Reformasi, Bertobat, dan Lahir Kembali" (pp. 84-87). Nyatalah bahwa penegasan Andar mengenai pendidikan karakter di keluarga, gereja dan lembaga gerejawi serta di masyarakat, dikemukakan berkesinambungan baik secara ekplisit maupun secara terselubung.

Uraian berikut selanjutnya mengemukakan topik-topik bahasan Seri Selamat, yang diharapkan meluaskan pengertian guru PAK tentang delapan belas karakter bangsa, yaitu: 1) Religius; 2) Jujur; 3) Toleransi; 4) Disiplin; 5) Kerja keras; 6) Kreatif; 7) 
Mandiri; 8) Demokratis; 9) Rasa ingin tahu; 10) Semangat Kebangsaan; 11) Cinta Tanah Air; 12) Menghargai Prestasi; 13) Bersahabat/Komunikatif; 14) Cinta Damai; 15) Peduli Lingkungan; 16) Gemar membaca; 17) Peduli Sosial; 18) Tanggung jawab. (Bahan Pelatihan, 2010, pp. 9-10). Dalam rangka mempersingkat pemaparan hasil penelitian, jenisjenis karakter bangsa itu digabungkan dalam uraian di bawah ini.

\section{Karakter Religius}

Dikemukakan dalam Bahan Pelatihan (2010, pp. 9-10) maksud "religius" ialah sikap dan perilaku yang patuh dalam melaksanakan ajaran agama yang dianutnya, toleran terhadap pelaksanaan ibadah agama lain, dan hidup rukun dengan pemeluk agama lain. Guru PAK dapat belajar dari beragam tulisan Andar mengenai nilai dan karakter religius. Berbakti (1999) mengemukakan sikap kritisnya terkait kekerasan agama melalui "Lagi-lagi Gereja Dibakar" (pp. 92-96). Berkiprah (2001) mengkritik sikap religius sempit melalui "Kalau Agama Dijadikan Kewajiban" (pp. 45-49). Dalam Sejahtera (2002) dikemukakan pentingnya harmoni beragam gereja pada "Ketika Gereja Berselisih Pendapat" (pp. 24-26), dan sikap terhadap fanatisme agama melalui "Garis Keras" (pp. 61-64).

Dalam Berpulih (2006) terdapat dalam sindiran Andar Ismail tentang kemunafikan di masyarakat pada judul "Katanya Kita Beragama" (pp. 5456). Berkarunia (2008) memuat kritik terhadap praktik beragama sempit dalam "Chauvinisme Religius" (pp. 37-40) dan "Mendewakan Agama" (pp. 126-128). Dalam Berpelita (2011) pada "Agama dan Negara: Untung atau Buntung?” (pp. 116-120) mengemuka kritik tajam Andar atas dominasi agama terhadap kebijakan negara.

Dalam Sehati (2013) Andar mengajak warga gereja bersikap positif saja ketika mendengar julukan "Orang Nasrani" (pp. 48-50) dari lingkungan sosialnya. Arti ungkapan itu kemudian dijelaskan. Dalam "Ketiga Agama Dinista" (pp. 55-58) Andar Islami mengajak orang Kristen maklum dan tabah.
Dalam Berpadu (2014) sikap menghargai agama dan denominasi lain dinyatakan melalui "Akidah Agama Lain" (pp. 5-8) dan "Hati-hati Gampang Pecah!" (pp. 68-73). Judul "Katolik dan Protestan, Sama atau Beda?" dalam Membarui (2017, pp. 125-129) menyatakan sikap religius sepatutnya dari warga jemaat Katolik dan Protestan di tengah kemajemukan agama. Akhirnya dalam Mengaku (2018) Andar Ismail menghadirkan pandangannya mengenai sikap religius terpuji, melalui "Cara Yesus Beragama" (pp. 49-52). Sementara itu dalam "Betulkah Yesus Menodai Agama?" (pp. 53-57), Andar Ismail mengkritik mudahnya kelompok tertentu di negeri ini menghukum seseorang dengan alasan menodai agama.

Paparan di atas memperlihatkan bahwa guru PAK dapat belajar karakter religius dari perspektif Alkitab, pengetahuan sosial dan budaya, refleksi pengalaman dan pengamatan pribadi. Selain itu, Seri Selamat menekankan karakter religius yang berpusat kepada Yesus Kristus bagi umat Kristen, seraya tetap toleran terhadap penganut agama dan warga denominasi lain. Pendekatan cerita dan diskusi sebagaimana diakomodasi oleh beragam tulisan Andar, dapat membangun nilai dan karakter religius yang baik.

Namun, pengembangan karakter religius tidak boleh dilakukan hanya sebatas pengajaran secara verbal, atau hanya melalui tulisan. Pebentukan karakter religius (Islam) menurut Kausar dan Edi (2017, pp. 259-277) patut dikembangkan melalui pembiasaan praktik ritual agama seperti sholat, membaca Kitab Suci dan memberi sedekah. Hal serupa ditegaskan oleh Wati dan Arif (2017, pp. 60-63). Namun, terobosan kreatif mengajarkan nilai religius tampaknya terus dibutuhkan. Sattriawan dan Sutiarso (2017), misalnya, mengelola pembelajaran karakter religius diintegrasikan dengan Matematika khususnya melalui topik simbol dan bilangan (pp. 191-196). Melalui pembelajaran tata bahasa simple present tense dan parts of speech di sekolah menengah, Ambarini (n.d., pp. 150-166), mengakui berhasil menanamkan karakter reli-gius dalam hal perlunya berkata, mem- 
bangun kalimat, dan memberi ucapan-ucapan positif dan negatif, serta kalimat interogatif.

\section{Karakter Jujur dan Menghargai Prestasi}

Dikemukakan oleh Bahan Pelatihan (2010) maksud "jujur" ialah perilaku yang didasarkan pada upaya menjadikan dirinya sebagai orang yang selalu dapat dipercaya dalam perkataan, tindakan, dan pekerjaan. Maksud "mengargai prestasi” ialah sikap dan tindakan yang mendorong dirinya untuk menghasilkan sesuatu yang berguna bagi masyarakat, dan mengakui, serta menghormati keberhasilan orang lain.

Dalam Melayani Tuhan (Ismail, 1996) pelajaran kejujuran ditekankan oleh "Mencari Keuntungan dari Kisah Derita" (pp. 70-72), "Engkau Menggemukkan Dirimu" (pp. 82-84), dan "Sampai Sumbu Penghabisan" (pp. 132-134). Pada Berkarya (Ismail, 1998) kejujuran disingkapkan oleh "Kambing Hitam” (pp. 126-129). Dalam Bergereja (Ismail, 1999) nilai hidup itu dikemukakan oleh "Budaya Poles" (pp. 35-37). Pada Mewaris (Ismail, 2005) perkara itu dinyatakakan dalam "Bersih Sampai Akhir?" (pp. 41-44).

Pada Berkarunia (Ismail, 2008) nilai kejujuran dikemukakan melalui sebuah kritik sosial berjudul "Republik Suap?" (pp. 30-32) dan semibiografi "Dr Johannes Leimena" (pp. 78-84). Semibiografi "Frans Tumiwa" dalam Bergereja (Ismail, 2009, pp. 107-110) dan "Frans Seda Jelas Beda" dalam Berpelita (Ismail, 2011, pp. 72-74) juga berbicara mengenai kejujuran dan menghargai. Dalam Berpadu (Ismail, 2014) minimnya karakter itu dituangkan dalam "Mulutnya Doang" (pp. 74-76). Berbuah (Ismail, 2015) menyerukan pendidikan nilai itu melalui semibiografi "Mandela dan Musuhnya" (pp. 25-28) dan "Johannes Verkuyl" (pp. 123128).

Andar Ismail sangat mendukung hadirnya kejujuran dalam hidup rakyat dan pejabat pemerintah, umat dan pimpinan agama, di negeri yang majemuk ini. Selain studi Alkitab, kritik sosial dan budaya, dan kisah-kisah hidup tokoh lebih menonjol dalam paparan di atas. Artinya, penanaman nilai dan penumbuhan kejujuran dan penghargaan atas prestasi secara tulus, membutuhkan model konsisten.

Perlunya teladan orang tua, guru, pemimpin dan pejabat di lembaga dalam membangun nilai dan karakter kejujuran juga diakui Emosda (2011). Ditekankan bahwa penanaman nilai kejujuran tidak bisa hanya melalui pengajaran yang masuk akal. Murid di skolah membutuhkan teladan guru dan tenaga kependidikan (pp. 151-166). Hal serupa juga dikemukakan oleh Amin (2017, pp. 105-124), tanpa mengabaikan peran pembelajaran, interaksi bermakna guru dengan murid, dan kegiatan-kegiatan diskusi dan refleksi. Berdasarkan hasil penelitiannya di sekolah, Wisesa (2017) memberi tekanan senada, dimana peran teladan dalam membangun kejujuran dan menghargai sangat fundamental (pp. 142-165).

\section{Karakter Toleransi dan Demokratis}

Dikemukakan dalam Bahan Pelatihan (2010) maksud "toleransi" ialah sikap dan tindakan yang menghargai perbedaan agama, suku, etnis, pendapat, sikap, dan tindakan orang lain yang berbeda dari dirinya. Maksud "demokratis" ialah cara berfikir, bersikap, dan bertindak yang menilai sama hak dan kewajiban dirinya dan orang lain.

Dalam Berkarunia (Ismail, 2008) nilai toleransi diperlihatkan Andar dalam tulisan-tulisan konseptual berjudul "Kecerdasan Majemuk" (pp. 53-56), "Multikultural" (pp. 70-73), "Mahluk Itu Majemuk" (pp. 110-113), dan "Pendidikan Kemajemukan" (pp. 122-125). Dalam Berkerabat (Ismail, 2010) nilai toleransi dikemukakan oleh "Kecerdasan Sosial" (pp. 16-19), "Salat Subuh" (pp. 27-29), dan Torang Samиа Basudara! (pp. 115-117).

Berpadu (Ismail, 2014) membahas kedua nilai hidup itu melalui "Satu-satunya Jalan?" (pp. 911), "Wanita Beda Martabat?" (pp. 12-15), "Kita Perlu Beda" (pp. 43-46), "Lesbian dan Gay" (pp. 8084), dan "Berani Berbeda" (pp. 108-111). Tampaknya Berpadu memuat cukup banyak tulisan tentang menghadapi perbedaan. 
Berbuah (Ismail, 2015) secara terselubung membahas nilai demokrasi melalui judul "Kita Menolak, Tetapi Allah Menerima" (pp. 129-131). Dalam Bercinta (2016) nilai dan perilaku toleran dibahas dalam "Tolak vs Terima" (pp. 56-59), dan eksposisi 1 Korintus 13 dengan judul "Cinta Bukan Hanya Perasaan” (pp. 127-129). Dalam Mengaku (2018) Andar mengemukakan pandangannya mengenai toleransi dalam "Menghakimi" (pp. 125-128), dan dalam refleksi pengetahuan budaya pada "Primordial: Baik atau Buruk?" (pp. 133-139).

Paparan di atas menyatakan bahwa sikap toleran dan demokratis bagi Andar Ismail harus didemonstrasikan saat menghadapi orang-orang yang berbeda latar belakang budaya, sosial, agama dan gender. Bahkan terhadap orang yang berorientasi LGBT sekalipun, Andar Ismail menyatakan perlunya karakter toleran. Warga jemaat dapat belajar dari Alkitab, pengetahuan, dan terutama teladan hidup orang tertentu.

Karakter toleransi dan demokratis ini dipandang pendidik lain patut dibangun sejak usia dini (35 tahun), agar saat bertumbuh remaja mereka lebih mudah diarahkan (Babuta \& Wahyurini, 2014, pp. 2337-3520). Selain kegiatan ekstrakurikuler dan penyediaan sarana dan prasana untuk interaksi bermakna, Taufan dan Sapriya (2018, pp. 17-29) menekankan pembelajaran kreatif di kelas tetap dibutuhkan.

Bagi Supriyanto dan Wahyudi (2017, pp. 61-70) indikator dari karakter toleransi perlu dirumuskan, sehingga mudah mengukur keberhasilan pembelajaran. Keduanya melihat bahwa karakter toleransi mencakup: peduli, tidak takut berbeda, cinta, menghargai perbedaan dan keunikan individu, terbu$\mathrm{ka}$, reseptif dan nyaman bersama orang yang berbeda. Jika demikian, tulisan-tulisan Andar di atas dapat dikatakan mampu berkontribusi bagi pengembangan karakter ini.

\section{Karakter Disiplin, Kerja Keras dan Mandiri}

Dituliskan oleh Bahan Pelatihan (2010) maksud "disiplin" ialah tindakan yang menunjukkan perilaku tertib dan patuh pada berbagai ketentuan dan peraturan. Kemudian, maksud "kerja keras" ialah perilaku yang menunjukkan upaya sungguhsungguh dalam mengatasi berbagai hambatan belajar dan tugas, serta menyelesaikan tugas dengan sebaikbaiknya. Selanjutnya, arti "mandiri" ialah sikap dan perilaku yang tidak mudah tergantung pada orang lain dalam menyelesaikan tugas-tugas.

Ribut Rukun (Ismail, 1994) memaparkan nilai kedisiplinan melalui "Susahnya Mengendalikan Keinginan" dan "Apa yang Dikecam Ayah Jangan Disanjung Ibu" (pp. 9-16). Mewaris (Ismail, 2005) mengemukakan hal itu dalam "Olimpiade, Malu Dong!" (pp. 66-68), dan "Tuhan Ambil Jalan Putar" (pp. 77-81). Dalam Berpulih (Ismail, 2006) topik "Menghasilkan Yang Terbaik" (pp. 50-53) dan "Pola Hidup New Start" (pp. 95-97) berbicara tentang kerja keras dan disiplin hidup sehat. Berkarunia (Ismail, 2008) membahas tema itu dalam "Kepribadian Loper Koran" (pp. 13-17) dan "Antri” (pp. 41-44). Dalam Berpadu (Ismail, 2014, pp. 127-131) disiplin, kerja keras dan mandiri diungkapkan oleh semibirografi "Yap Thiam Hien".

Nilai dan karakter kerja keras secara khusus diperlihatkan oleh banyak judul dalam Berkarya (Ismail, 1998). Warga jemaat dibimbing memahami dasar teologi kerja, melalui, "Allah Jadi Tukang Kayu" (pp. 1-4), "Panggilan Tuhan" (pp. 5-8), "Tiada Kerja Yang Hina" (pp. 42-46), "Yesus Tukang Kayu” (pp. 52-54), dan "Krisis versus Kemudahan" (pp. 73-79), dan "Kamulah Tangan-Ku" (pp. 130134). Karya duapuluh tahun silam ini disebut Andar Ismail membahas spiritualitas kerja.

Nilai kerja keras masih dibahas pada Berbuah (Ismail, 2015), melalui ulasan tentang tokoh Alkitab Otniel (pp. 43-44). Judul "Mandiri atau Bergantung?" (pp. 97-100) dan "Masih berbuah Sampai Tua" (pp. 132-135) menguatkan pesan itu. Dalam Bercinta (2016, pp. 98-100) dikemukakan semibiografi seorang psikolog pekerja keras, dalam "Komitmen Singgih Gunarsa".

Paparan di atas menyatakan bahwa Andar Ismail telah menjadi teladan dalam karakter ini. Pe- 
ran teladan dalam pembentukan disiplin dan kerja keras, juga ditekankan Handayani dan Sumaryati (2014, pp. 27-38) berdasarkan studi kasus mereka. Peran teladan dan kerja keras dosen untuk membangun disiplin, kemandirian dan kerjasama mahasiswa melalui tugas-tugas perkuliahan, dibuktikan positif oleh Ikhwanuddin (2012, pp. 153-162). Wiranto (2015) menemukan bahwa penegakan disiplin berpengaruh positif bagi kinerja dan kerja keras pengrajin tembaga di sebuah lokasi, sehingga pengrajin itu dapat mengejar target produksi yang diharapkan.

\section{Karakter Kebangsaan dan Cinta Tanah Air}

Dikemukakan oleh Bahan Pelatihan (2010) maksud "semangat kebangsaan" ialah caraberpikir, bertindak, dan berwawasan yang menempatkan kepentingan bangsa dan negara di atas kepentingan diri dan kelompoknya. Maksud "cinta tanah air" ialah cara berfikir, bersikap, dan berbuat yang menunjukkan kesetiaan, kepedulian, dan penghargaan yang tinggi terhadap bahasa, lingkungan fisik, sosial, budaya, ekonomi, dan politik bangsa.

Dalam Membarui (Ismail, 2018) nilai-nilai cinta tanah air terdapat dalam "Gereja Butuh Konteks" dan "Konteksnya Konteks Indonesia" (pp. 5866). Kedua judul itu mengingatkan gereja agar memahami dan meresponi konteksnya secara kreatif. Topik-topik dalam Bercinta (Ismail, 2016), yaitu “Ketika Bung Karno Bangkit Kembali” (pp. 72-76) dan "Cinta Diri, Benci Korupsi" (pp. 90-93) pun mengungkapkan dua nilai budaya di atas. Pada Berpadu (Ismail, 2014, pp. 64-67), nilai kebangsaan dan cinta tanah air tersingkap dalam "Bhinneka Tunggal Ika".

Dalam Berpelita (Ismail, 2011) terdapat bahasan-bahasan "Jiwa Luhur Gus Dur" (pp. 28-32), "Frans Seda Jelas Beda" (pp. 72-74), "Habis Gelap Terbitlah Terang" (pp. 79-83), yang semuanya mengemukakan teladan cinta tanah air. Dalam Bergereja (Ismail, 2009) judul "Frans Tumiwa" (pp. 107-110) dan "Frindolin Ukur" (pp. 19-25) memaparkan dua tokoh Kristen yang peduli kebangsaan.
Jika Andar mengemukakan pendekatan naratif membangun karakter kebangsaan dan cinta tanah air warga jemaat, Suti (2017) mengamati praktik di sebuah sekolah menengah yang menerapkan kegiatan ekstrakurikler, termasuk aktivitas pramuka, upacara bendera, seni tari dan budaya Indonesia, dan mengenali serta latihan mempromosikan hasil karya masyarakat di tanah air. Perlunya pendekatan serupa juga ditegaskan oleh Priyambodo (2017, pp. 9-15) berdasarkan hasil studinya di kota Pasuruan, Jawa Timur, juga oleh Siwiyanti (2017) yang meneliti sebuah sekolah di Kebumen. Selain belajar dari tulisan-tulisan kreatif, pembelajaran kebangasaan dan cinta tanah air juga patut dikelola melalui praktik.

\section{Karakter Bersahabat/ Komunikatif}

Dikemukakan oleh Bahan Pelatihan (2010) maksud "bersahabat/komunikatif" ialah tindakan yang memperlihatkan rasa senang berbicara, bergaul, dan bekerja sama dengan orang lain. Ada dua sumber penting yang dapat membantu guru PAK memahami nilai dan karakter bangsa ini.

Pertama, Berteman (Ismail, 2007) secara khusus memuat pemikiran, perenungan, dan pengalaman Andar Ismail menegnai persahabatan. Buku itu memuat landasan Alkitab dan teologi persahabatan, yakni "Allah Mau Bertamu"(pp. 1-3), "Mendekat dan Melekat" (pp. 4-6), "Yonatan" (pp. 1014), “Injil Petrus?” (pp. 40-43), dan "Dia Tetap Menunggu" (pp. 53-55). Sajian lain ialah kisah-kisah tokoh yang dipandang Andar bermakna bagi hidupnya, termasuk "Juffrow Thio" (pp. 15-17), "Eka Teman Sekelas?" (pp. 56-58), "Berteman Kasamba" (pp. 66-68), "Johan Komensky" (pp. 76-78), dan "Sobron Aidit" (pp. 105-108). Bentuk paparan lainnya ialah ulasan film tentang orang kesepian "Patch Adams" (pp. 18-20) dan novel "Robinson Crusoe" (pp. 102-104). Sajian yang bersifat pengetahuan ialah "Hewan Sebagai Kawan" (pp. 79-82) dan "Pendidikan Persahabatan" (pp. 109-112).

Kedua, Berkerabat (Ismail, 2010, pp. 16-19) mengemukakan nilai dan cara membangun kebersamaan dalam "Kecerdasan Sosial". Paparan lain ber- 
bentuk semibiografi kerabat, yakni "Emak dan Engkong” (pp. 46-49), "Om dan Tante Kho" (pp. 5053), "Sularso Sopater" (pp. 57-60) dan "Peter Latuihamallo" (pp. 75-79). Pemahaman Alkitab yang dapat menjadi landasan bersahabat ialah "Yonatan dan Ajudan" (pp. 5-8), "Tiga Cara Berada" (pp. 912), "Ruman Ibu Lidia" (pp. 13-15), dan judul "Dicintai, tetapi Melukai" (pp. 121-124). Berbuah (Ismail, 2015) menyajikan dua bahan pengajaran yaitu "Damai Dengan Saudara Kandung" (pp. 1619) dan "Komunikasi” (pp. 45-48).

Jika guru PAK dapat melihat beragam pemahaman pendidikan karakter bersahabat dari Seri Selamat, mereka dapat pula menyimak usulan Zainuddin (2013, pp. 69-76) tentang penanaman nilai dan karakter itu melalui pendekatan interaksi, kerjasama dan diskusi kelompok yang dinamakan group investigation. Dari penelitiannya, Zainuddin menyatakan bahwa pendekatan itu dapat meningkatkan hasil belajar dan mengembangkan karakter siswa. Jika Andar Ismail membekali warga jemaat dewasa agar giat menuntun anak belajar bersahabat dan berkomunikasi, Sukirman (2016) menciptakan pedoman sederhana, yang isinya membahas arti, tujuan, alasan dan metode pendidikan persahabatan bagi anak.

\section{Karakter Gemar Membaca, Rasa Ingin Tahu, dan Kreatif}

Dikemukakan oleh Bahan Pelatihan (2010) maksud "gemar membaca" ialah kebiasaan menyediakan waktu untuk membaca berbagai bacaan yang memberikan kebajikan bagi dirinya. Maksud "rasa ingin tahu" ialah sikap dan tindakan yang selalu berupaya untuk mengetahui lebih mendalam dan meluas dari sesuatu yang dipelajarinya, dilihat, dan didengar. Selanjutnya, maksud "kreatif" ialah berpikir dan melakukan sesuatu untuk menghasilkan cara atau hasil baru dari sesuatu yang telah dimiliki.

Masukan-masukan berharga terkait nilai dan karakter ini disajikan dalam Mengaku (Ismail, 2018) melalui "Siapa Lagi Kalau Bukan Abineno" (pp. 115-119), "Melanchthon Mengaku Keunggulan Teman” (pp. 120-124). Dalam Membarui (Ismail, 2017) karakter itu diungkapkan oleh teladan tokoh reformasi Yohanes Calvin, dalam"Calvin: Anak Yatim Piatu Jadi Pembaru Gereja" (pp. 51-53) dan "Calvin: Berubah Arah di Losmen Murah" (pp. 54-57).

Berbuah (Ismail, 2015, pp. 123-128) memuat kisah hidup "Johannes Verkuyl”. Sehati (Ismail, 2013, pp. 80-84) berbicara tentang "Leo Tolstoy". Berpelita (Ismail, 2011, pp. 79-83) memuat kisah tokoh yang gemar membaca yaitu R.A. Kartini dibahasnya dalam "Habis Gelap Terbitlah Terang". Kedua kisah tokoh itu menekankan pentingnya gemar membaca, rasa ingin tahu dan kreatif.

Dalam Bergereja (Ismail, 2009) "Pendeta yang Belum Bertobat" (pp. 15-18), "Ketika Pendeta Berbahasa" (pp. 81-84), dan "Gereja Yang Membaca dan Menulis" (pp. 99-102), semuanya menekankan pentingnya gemar membaca. Berpulih (Ismail, 2006, pp. 57-60) memuat semibiografi "Henry Nouwen" yang kreatif menulis dan secara terselubung meninggalkan teladan bagi Andar Ismail. Sejahtera (Ismail, 2002, pp. 53-56) memuat semibiografi Erasmus, pengarang ternama di Belanda, dalam "Aku Warga Segala Bangsa”. Berkiprah (Ismail, 2001, pp. 10-14) menuliskan semibiografi penulis puisi "Kahlil Gibran". Bergumul (Ismail, 2000) memuat semibiografi "Jean Jacques Rousseau" (pp. 30-34), dan "Hans Christian Andersen" (pp. 127-130), dimana dimana keduanya menyingkapkan teladan serupa.

Didik-Mendidik (Ismail, 1997, ) berisi motivasi supaya orang gemar membaca, yaitu "Apa Orang Berusia Masih Bisa Belajar" (pp. 67-70), “Apa Gereja Kita Sibuk Belajar?” (pp. 9-91). Mengikut Dia (Ismail, 1994) berbicara tentang nilai gemar membaca dan kreatif dalam "Apakah Yesus Pernah Bersekolah?" (pp. 66-70). Tampaklah bahwa sudah duapuluh delapan tahun gemar membaca ditekankan Andar.

Paparan di atas menyatakan ketekunan Andar Ismail mengajarkan nilai gemar membaca. Dalam beberapa tulisan ditegaskan bahwa Seri Selamat merupakan buah dari kegemarannya membaca sejak di sekolah dasar dan menengah. Bakatnya mengarang dan menulis yang bertumbuh dan dikembang- 
kan sejak sekolah menengah pertama, turut menjadi faktor penting dalam menghasilkan buku-buku renungan. Secara terselubung Andar Ismail meniru tokoh-tokoh yang disebutkan di atas, seperti Calvin, Erasmus, Tolstoy, Henry Nouwen, dan Verkuyl.

Menumbuhkan karakter gemar membaca pada anak juga remaja, pada umumnya tidaklah mudah. Tampak seolah mendukung upaya Andar menghasilkan tulisan-tulisan ringkas bersifat naratif dan humoris, Ambarwati (2017, pp.1-11) meneliti bahwa cerita pendek dan humor yang dibaca anak dapat meningkatkan nilai gemar membaca mereka. Zuhri (n.d. pp. 1-13) menyatakan bila siswa di sekolah dimotivasi untuk melakukan free voluntary reading (FVR), dimana mereka bebas memilih bahan bacaan di luar buku bacaan mata pelajaran, maka minat baca mereka meningkat signifikan. Jadi, selain cara membangkitkan minat baca warga jemaat dengan tulisan populer, masih ada pendekatan kreatif lain yang dapat dan patut diteliti serta dikembangkan oleh guru PAK dan pembina warga jemaat.

\section{Karakter Peduli Sosial}

Dikemukakan oleh Bahan Pelatihan (2010), maksud "peduli sosial" ialah sikap dan tindakan yang selalu ingin memberi bantuan pada orang lain dan masyarakat yang membutuhkan. Tulisan awal Andar Ismail mengenai peduli sosial ialah "Memberi Secara Kristiani” dalam Panjang Umur (Ismail, 1995, pp. 83-86). Kemudian, dalam Melayani Tuhan (Ismail, 1996) hadir sejumlah tulisan serupa, yaitu "Orang Miskin Selalu Ada Padamu" (pp. 21-25), "Perlukah Gopal Menunggu Sampai Leela Mati?" (pp. 42-44), dan "Setiap Kali kalau Tukang Bubur Itu Datang" (pp. 100-102) tentang peduli sosial ibunda Andar.

Dalam Berkiprah (Ismail, 2001, pp. 64-66) kepedulian sosial dikemukakan oleh pelayanan diakonia "Ibu Tiong Tjeng”. Dalam Bergereja (Ismail, 2009) perkara itu diungkapkan oleh "Hak Anak" (pp. 36-39), "Gereja yang Ikut Bersedih" (pp. 5356), "Komunitas Yang Peduli” (pp. 73-76), dan judul "Diskriminasi" (pp. 120-123).
Dalam Berkerabat (Ismail, 2010) kepedulian sosial dibahas pada"Kecerdasan Sosial” (pp. 16-19) dan "Ada Orang Baik!" (pp. 111-114). Dalam Berjuang (2012) nilai hidup itu dikemukakan oleh "Menemani yang Hampir Meninggal" (pp. 37-40), "Bila Orang tua Jadi Renta" (pp. 57-60), dan "Kematian Orang Terdekat" (pp. 87-89).

Dalam Sehati (Ismail, 2013, pp. 12-14) kepedulian sosial dikemukakan melaluiteladan Yesus dalam “Turun dari Gunung Kemuliaan”. Dalam Berpadu (Ismail, 2014) hal itu dinyatakan oleh kritik sosial dalam "Mulutnya Doang (pp. 74-76), dan kisah pembela orang miskin "Yap Thiam Hien" (pp. 127-131). Pada Berbuah (Ismail, 2016, pp. 43-44) aspek itu dibahas dalam "Otniel". Dalam Bercinta (2016, pp. 134-139) nilai di atas diungkapkan oleh judul "Cinta Penyandang Demensia".

Paparan di atas menyatakan bahwa bagi Andar Ismail, iman Kristen harus nyata dalam tindakan kasih kepada sesama. Peduli sosial tidak boleh sebatas wacana. Alkitab, kisah hidup tokoh, pengalaman pribadi, pengetahuan sosial, semua dipergukan Andar Ismail menyampaikan nilai luhur itu.

Agar tidak sebatas wacana dan diskusi verbal, menurut Sifa (2015) dan Masrukhan (2016) pembentukan dan pengembangan karakter peduli sosial anak dan remaja di sekolah, membutuhkan tindakan konkrit berupa kegiatan kreatif dan variatif ekstrakurikuler, yang mesti diperkuat oleh keteladanan guru. Menurut Warsiah (n.d, pp. 1-25) guru di sekolah harus merencanakan dan melaksanakan kegiatan-kegiataninteraksi sosial diantara guru dengan siswa, dan diantara para siswa. Kegiatan itu akhirnya patut dievaluasi untuk peningkatan mutu.

\section{Cinta Damai}

Dikemukakan oleh Bahan Pelatihan (2010) maksud "cinta damai" ialah sikap, perkataan, dan tindakan yang menyebabkan orang lain merasa senang dan aman atas kehadiran dirinya. Selamat Sejahtera (Ismail, 2002) secara khusus memuat nilai dan karakter damai dan pendidikan pendamaian. Sejumlah tulisan dalam Sejahtera (Ismail, 2002) 
berbicara mengenai beragam upaya beroleh damai, yang dikemukakan dalam "Syalom" (pp. 4-7), "Ktika Gereja Berselisih Pendapat" (pp. 24-26), "Desa Hancock" (pp. 27-30), "Berdamai di Meja Makan" (pp. 31-34), "Yang Berjiwa Besar" pp. 49-52), "Dimulai dari Diri Sendiri" (pp. 70-73), "Pendidikan Kedamaian" (pp. 111-114), dan "Semoga" (pp. 124127).

Tulisan lain mengenai cinta damai terdapat dalam Mewaris (Ismail, 2005) yakni pada "Peniup Suling dari Hamalin" (pp. 33-36), dan "Ketika Kita Kecewa” (pp. 56-58). Dalam Berpulih (Ismail, 2006) tulisan yang membicarakan nilai dan karakter itu ialah "Harmoni" (pp. 14-16). Dalam Berteman (Ismail, 2007) terdapat pemikiran cinta damai pada "Yonatan" (pp. 10-14) dan "Abigail" (pp. 86-89). Dalam Bergereja (Ismail, 2009) ketiadaan cinta damai dikemukakan oleh "Gereja Dianiaya" (pp. 5760) dan "Diskriminasi" (pp. 120-123).

Dalam Berkerabat (Ismail, 2010), cinta damai dinyatakan oleh judul "Yonatan dan Ajudan" (pp. 9-12), dan "Sebotol Racun Cinta" (pp. 86-89). Dalam Berpadu (Ismail, 2014, pp. 23-26) perkara itu diungkapkan oleh "Orang Lain: Surga atau Neraka". Dalam Sehati (Ismail, 2013) dikemukakan pada "Mertuaku" (pp. 51-54), "Persaingan Antara Yohanes dan Petrus" (pp. 59-62).

Dalam Berbuah (Ismail, 2015) cinta damai diungkapkan oleh judul "Membawa Damai" (pp. 811), "Damai dengan Saudara Kandung" (pp. 16-19), "Mandela dan Musuhnya" (pp. 25-28), dan "Memberi Diri Didamaikan" (pp. 105-107). Tampak bahwa karakter di atas dibahas melalui semibiografi, studi Alkitab dan refleksi kehidupan.

Tulisan yang mengajarkan cinta damai jumlahnya cukup signifikan. Menarik mengamati bahwa pesan cinta dan kasih dalam dalam wujud kedamaian pada Bercinta, menguatkan pelajaran-pelajaran serupa yang pernah dimuat dalam Sejahtera (Ismail, 2002). Berjuang (Ismail, 2012) memuat tulisan tentang keuletan menyatakan damai di tengah krisis hidup. Berpadu (Ismail, 2014) mengemukakan upaya damai di tengah masyarakat majemuk.
Dalam rangka penguatan perlu kiranya guru PAK memahami bahwa pendidikan nilai dan karakter cinta damai di kalangan remaja sangat penting guna membantu mereka menghadapi bullying teman sebayanya (Afiyatun, 2013). Dalam rangka menguatkan pembelajaran karakter cinta damai melalui materi bacaan yang disajikan Seri Selamat, masih diperlukan pendekatan lain. Solaikah (2014) menawarkan kegiatan menonton dan diskusi reflektif film cinta damai seperti Di Timur Matahari untuk siswa SMP. Perlu diingatkan pula bahwa untuk menumbuhkan cinta damai pada diri remaja, Bachri dan Suharnan (2014) memandang perlu pembangunan kecerdasan emosi dan kemampuan persepsi yang benar. Jujud-judul dari Seri Selamat di atas, dinilai penulis berkontribusi untuk menumbuhkan kecerdasan emosi dan persepsi dimaksud.

\section{Karakter Tanggungjawab}

Dikemukakan oleh Bahan Pelatihan (2010) maksud "tanggung jawab" ialah sikap dan perilaku seseorang untuk melaksanakan tugas dan kewajibannya, yang seharusnya dia lakukan, terhadap diri sendiri, masyarakat, lingkungan (alam, sosial dan budaya), negara dan Tuhan Yang Maha Esa.

Hampir seperempat abad yang lalu Andar sudah menekankan pentingnya nilai dan karakter bertanggung jawab di tanamkan orang tua melalui "Menumbuhkan Sifat Watak Bertanggung jawab" dalam RibutRukun (Ismail, 1993, pp. 29-33). Pelayan Tuhan ditekankan harus terdepan sebagai model bertanggung jawab, yang dikemukakan Andar Ismail melalui "Sampai Sumbu Penghabisan" (Ismail, $M e$ layani Dia, 1996, pp. 132-134). Kritik terhadap perilaku tidak bertanggung jawab dalam konteks pendidikan dan sekolah, dinyatakan oleh judul "Mental Jalan Pintas" pada Menabur (Ismail, 1997, pp. 112115).

Buku spiritualitas kerja, Berkarya (Ismail, 1998, pp. 126-129), pun turut membahas kritik terhadap perilaku tidak bertanggung jawab, dalam “Kambing Hitam”. Dalam Berpulih (Ismail, 2005) tanggung jawab diajarkan oleh "Bersih Sampai Ak- 
hir" (pp. 41-44), dan oleh tokoh Alkitab, Timotius (pp. 62-65). Topik "Bertahan Bak Bambu" dalam Berpulih (Ismail, 2006, pp. 47-49), serta "Rutin" (pp. 69-71) dan “Abigail” (pp. 86-89) dalam Berteman (Ismail, 2007), semuanya berbicara tentang nilai tanggung jawab. Nilai dan karakter itu dalam Berkarunia (Ismail, 2008, pp. 78-84) dikemukakan Andar Ismail melalui semibiografi "Dr. Johannes Leimena".

Nilai bertanggung jawab juga dikemukakan oleh semibiografi mereka yang mencintai tanah air, termasuk "Frans Tumiwa" (Ismail, Bergereja, 2009, pp. 107-110), "Peter D. Latuihamallo" (Ismail, Berkerabat, 2010, pp. 75-79), "Frans Seda Jelas Beda" (Ismail, Berpelita, 2011, pp. 75-78), dan R.A.Kartini dalam "Habis Gelap Terbitlah Terang" (Ismail, 2011, pp. 79-83).

Dalam Berpadu, Andar Ismail (2014) menekankan karakter tanggung jawab dalam judul "Supaya Ahok Tetap Beda" (pp. 89-92), "Berani Berbeda" (pp. 108-111) dan "Yap Thiam Hien" (pp. 127-131). Berbuah (Ismail, 2015) mengemukakan pelajaran itu melalui "Mandela dan Musuhnya" (pp. 25-28), "Otniel" (pp. 43-44), dan "Johannes Verkuyl" (pp. 123-128).

Cerita keteladan hidup orang-orang yang bertanggung jawab sangat menonjol dalam paparan di atas. Andar memahami bahwa membaca kisah hidup dan karya tokoh-tokoh penting dapat membangkitkan rasa tanggung jawab. Pendekatan demikian juga dikemukakan oleh Rukiyati, Suhartini dan Priyoyuwono (2014, pp. 213-224) dalam pendidikan mahasiswa untuk memahami tema Guru Profesional. Secara berkelompok mahasiswa diberi tugas mempelajari tokoh-tokoh pendidikan ternama, kemudian menyajikan hasil diskusi mereka itu di kelas. Dilia bahwa kegiatan itu mampu menumbuhkan rasa tanggung jawab dan kebersamaan untuk berhasil dalam studi.

Ardila, Nurhasanah dan Salimi (2017) mengusulkan pendekatan kognitif dalam membangun tanggung jawab anak didik, seperti kegiatan mind mapping dan inquirying what you know. Ditemukan bahwa kegiatan itu secara signifikan membangun rasa tanggung jawab, sebab setiap siswa di kelas dimotivasi untuk berani terbuka atas apa yang dipikirkan dan direncakan, serta dikerjakan dan dievaluasi. Paparan di atas menunjukkan bahwa cukup banyak tulisan Andar Ismail yang dapat membangun kognisi bahkan membangkitkan afeksi pembaca Seri Selamat mengenai nilai tanggung jawab.

\section{KESIMPULAN}

Peraturan pemerintah untuk menguatkan pendidikan karakter yang sudah dilangsungkan sejak awal tahun 2010 yang lalu, membuka ruang bagi guru PAK di sekolah dan pembina warga jemaat di gereja untuk mengelola dan meningkatkan pembelajaran berbasis karakter. Dalam kaitan itu guru PAK dan pembina warga jemaat patut memahami pendekatan kreatif mengajarkan iman Kristen berbasis karakter, dengan delapan belas nilai dan karakter bangsa sebagai kerangka kerja. Upaya itu akan menuntun anak didik atau warga jemaat mempelajari iman melalui tugas-tugas dan panggilan hidup dalam konteksnya. Sebaliknya, mereka belajar memahami pergumulan dan tantangan dalam hidup keseharian dalam terang iman Kristen. Untuk itu guru dan pembina jemaat membutuhkan sumber bacaan yang memperluas wawasan dan membangkitkan komitmen bagi transformasi karakter pribadi dan sesamanya.

Seri Selamat merupakan materi PAK warga gereja dewasa yang ditulis Andar Ismail dalam bentuk renungan poupler. Seri Selamat mengajak warga gereja mempelajari Alkitab secara kreatif. Buku-buku renungan itu juga memuat pengajaran tentang nilai hidup dan karakter yang disajikan dalam bentuk tulisan hasil eksposisi Alkitab, refleksi pribadi, ulasan cerita rakyat dan budaya, kisah tokoh yang patut dijadikan teladan, dan paparan mengenai praktik hidup karakter.

Hasil studi Seri Selamat yang dipaparkan di atas diduga dapat memberi penguatan bagi guru PAK dan pembina warga jemaat, gunameningkatkan pembelajaran karakter berbasis iman Kristen. De- 
ngan menggunakan topik-topik dalam Seri Selamat, dan juga mempertimbangkan hasil-hasil penelitian para pendidikan karakter konteks sekolah sebagaimana dikemukakan di atas, guru PAK dan pembina jemaat dapat mengembangkan pembelajaran agama berbasis karakter dengan pendekatan olah pikir, olah

\section{DAFTAR RUJUKAN}

Aeni, A.N. 2014. "Pendidikan Karakter Untuk Siswa SD Dalam Perspektif Islam," Mimbar Sekolah Dasar, 1.1., 50-58.

Afiyatun, Ummu. 2013. "Pengembangan Nilai Cinta Damai Untuk Mencegah Bullying di Sekolah Dalam Rangka Membentuk Karakter Kewarganegaraan (Studi Kasus di SMA Kecamatan Gemolong, Kabupaten Sragen)." Skripsi. Pendidikan Pancasila dan Kewarganegaraan. Fakultas Keguruan dan Ilmu Pendidikan Universitas Sebelas maret, Surakarta.

Ambarwati, Ari. 2017. "Penguatan Karakter Gemar Membaca Melalui Cerpen Humor Untuk Anak Sekolah Dasar." https://www. researchgate.net/.../318381515_penguatan_ka rakter_gemar_membaca_melalui_cerpen_hu mor_untuk_anak_sekolah_dasar. Diunduh 01 November 2018, Pkl. 16.49 wib.

Amin, Muhammad. 2017. "Peran Guru Dalam Menanamkan Nilai Kejujuran Pada Lembaga Pendidikan,” TADBIR: Jurnal Studi Manajemen Pendidikan, Vol. 1, No. 01,105-124.

Akbar, Sa'dun., Ahmadi Samawi, Muh. Arafiq, Layli Hidayah. 2014. "Model Pendidikan Karakter yang Baik (Studi Lintas Situs Best Practices) Pendidikan Karakter di SD," Sekolah Dasar, 23.2, 138-151.

Ambarini, Riri. 2017. "Integrasi Pendidikan Karakter Religius dan Pembelajaran Tematik dalam Pengajaran Grammar," Lensa: Kajian Kebahasaan, Kesustraan dan Budaya, 7 (2): 150-166.

Ardila, Risma Mila., Nurhasanah, Moh Salimi. 2017. "Pendidikan Karakter Tanggung Jawab dan Pembelajarannya Di Sekolah." Pro- rasa, olah karsa sebagaimana ditekankan pendidikan nasional. Melalui saluran-saluran studi Alkitab, studi cerita-cerita rakyat, kisah hidup tokoh, contoh-contoh praktik sebagaimana diusulkan N.T.Wright, guru PAK dan peserta didiknya diharapkan mengalami transformasi karakter.

siding Seminar Nasional Inovasi Pendidikan, https://jurnal.fkip.ac.id/index.php/ snip/article/views/11151.

Babuta, Yoddie Y.I. \& Dwi Wahyurini. 2014. "Karakter Toleransi dan Cinta Damai Sejak Usia Dini (3-5 tahun)." Jurnal Sains Dan Seni Pomitis, 3 (1): 2337-3520.

Bass, Dorothy C. (ed.). 2010. Practicing Our Fatih. Revised Edition. SanFranciso: Jossey-Bass Publisher.

Bessie, Y. \& Margiot Tua Butarbutar. 2013. Pendidikan Agama Kristen \& Budi Pekerti: Hidup Beriman. Jakarta: BPK Gunung Mulia.

Bessie, Y. \& Nofedin Waruwu. 2013. Pendidikan Agama Kristen dan Budi Pekerti: Hidup yang Dibarui. Jakarta: BPK Gunung Mulia.

Booth, W.C., Gregory G. Colomb, \& Joseph M. Williams. 1995. The Craft of Research. Chicago: The University of Chicago.

Butarbutar, M.T.\& Yethie Bessie. 2013. Pendidikan Agama Kristen \& Budi Pekerti: Hidup Peduli. Jakarta: BPK Gunung Mulia.

Cermin Remaja 3. 2013. Pendidikan Agama Kristen: Hidup Yang Berbuah. Jakarta: BPK Gunung Mulia.

Creswell, J.W. 2013. Qualitative \& Research Design: Choosing Among Five Approaches. Los Angeles: SAGE.

Colson, Howard P. dan Raymond M. Rigdon. 1981. Understanding Your Church's Curriculum. Revised Edition. Nashville, Tenesse: Boradman Press.

Dhiu, K.\& Nikodemus Bate. 2017."Pentingnya Pendidikan Karakter di Perguruan Tinggi," 
$2^{\text {nd }}$ Annual Proceeding, (November), 172176.

Dykstra, Craig. 2005. Growing in the Life of Faith: Education and Christian Practices. $2^{\text {nd }}$ Edition. Louisville: Westminster John Knox Press.

Farida, I. 2012. "Model Pendidikan Karakter di Perguruan Tinggi: Langkah Strategis dan Implementasinya di Universitas," Jurnal Ilmiah Administrasi Publik dan Pembangunan, 3 (1): 445-452.

Handayani, Nita Warih. \& Sumaryati. 2014. "Upaya Orang Tua Dalam Menanamkan Karakter Kerja keras Anak Usia Remaja di Dusun Tegalyoso Banyuraden Gamping Sleman Yogyakarta," Jurnal Citizenship, 4 (1): 27-38.

Hartono, H. 2014. "Membentuk Karakter Kristen Pada Anak Keluarga Kristen, "Kurios (Jurnal Teologi dan Pendidikan Agama Kristen), 2 (1): 62-69.

Hj. Emosda. 2011. "Penanaman Nilai-nilai Kejujuran dalam Menyiapkan Karakter Bangsa," Innovatio, X (1): 151-166.

Ikhwanuddin. 2012. "Implementasi Pendidikan Karakter Kerja Keras dan Kerjasama Dalam Perkuliahan," Jurnal Pendidikan Karakter, II (2): 153-163.

Issler, K. 2012. The Formation of Christian Character: Living into the Life of Jesus. Downers Grove, Illinois: IVP Books.

Ismail, A. 1993. Selamat Ribut Rukun: 33 Renungan tentang Keluarga. Jakarta: BPK Gunung Mulia.

Ismail, A. 1994. Selamat Mengikut Dia: 33 Renungan tentang Kristus. Jakarta: BPK Gunung Mulia.

Ismail, A. 1995. Selamat Panjang Umur: $33 R e-$ nungan tentang Hidup. Jakarta: BPK Gunung Mulia.

Ismail, A. 1996. Selamat Melayani Tuhan: 33 Renungan tentang Pelayanan. Jakarta: BPK Gunung Mulia.
Ismail, A. 1997. Selamat Menabur: 33 Renungan tentang Didik-Mendidik. Jakarta: BPK Gunung Mulia.

Ismail, A. 1998. Selamat Berkarya: 33 Renungan tentang Kerja. Jakarta: BPK Gunung Mulia.

Ismail, A. 1999. Selamat Berbakti: 33 Renungan tentang Ibadah. Jakarta: BPK Gunung Mulia.

Ismail, A. 2000. Selamat Bergumul: 33 Renungan tentang Iman. Jakarta: BPK Gunung Mulia.

Ismail, A. 2001. Selamat Berkiprah: 33 Renungan tentang Kesaksian. Jakarta: BPK Gunung Mulia.

Ismail, A. 2002. Selamat Sejahtera: 33 Renungan tentang Kedamaian. Jakarta: BPK Gunung Mulia.

Ismail, A. 2003. Selamat Berkembang: 33 Renungan tentang Spiritualitas. Jakarta: BPK Gunung Mulia.

Ismail, A. 2005. Selamat Mewaris: 33 Renungan tentang Pusaka Hidup. Jakarta: BPK Gunung Mulia.

Ismail, A. 2006. Selamat Berpulih: 33 Renungan tentang Pemulihan. Jakarta: BPK Gunung Mulia.

Ismail, A. 2007. Selamat Berteman: 33 Renungan tentang Hubungan. Jakarta: BPK Gunung Mulia.

Ismail, A. 2008. Selamat Berkarunia: 33 Renungan tentang Hidup Majemuk. Jakarta: BPK Gunung Mulia.

Ismail, A. 2009. Selamat Bergereja: 33 Renungan tentang Komunitas Iman. Jakarta: BPK Gunung Mulia.

Ismail, A. 2010. Selamat Berkerabat: 33 Renungan tentang Kebersamaan. Jakarta: BPK Gunung Mulia.

Ismail, A. 2011. Selamat Berpelita: 33 Renungan tentang Alkitab. Jakarta: BPK Gunung Mulia.

Ismail, A. 2012. Selamat Berjuang: 33 Renungan tentang Perjuangan Hidup. Jakarta: BPK Gunung Mulia. 
Ismail, A. 2013. Selamat Sehati: 33 Renungan tentang Sehati Sepikir. Jakarta: BPK Gunung Mulia.

Ismail, A. 2014. Selamat Berpadu: 33 Renungan tentang Perbedaan. Jakarta: BPK Gunung Mulia.

Ismail, A. 2015. Selamat Berbuah: 33 Renungan tentang Tugas Hidup. Jakarta: BPK Gunung Mulia.

Ismail, A. 2016. Selamat Bercinta: 33 Renungan tentang Komitmen. Jakarta: BPK Gunung Mulia.

Ismail, A. 2017. Selamat Membarui: 33 Renungan tentang Reformasi Diri. Jakarta: BPK Gunung Mulia.

Ismail, A. 2018. Selamat Mengaku: 33 Renungan tentang Identitas. Jakarta: BPK Gunung Mulia.

Kautsar, Andri. \& Johan Edi. 2017. "Pendidikan Karakter Religius, Disiplin dan Bakat Melalui Peningkatan Kualitas Sarana Prasarana Sekolah," Jurnal Manajemen, Kepemimpinan, dan Supervisi Pendidikan, 2 (2): 259-277.

Kementerian Pendidikan Nasional. 2010. Bahan Pelatihan Pengembangan Pendidikan Budaya dan Karakter Bangsa.

Kementerian Pendidikan Nasional. 2011. Pedoman Pelaksaan Pendidikan Karakter.

"Kurikulum Berbasis Kompetensi (KBK) Pendidikan Agama Kristen.” 2003. Pusat Kurikulum Departemen Pendidikan Nasional.

Lie, Anita. 2014. "Religious Education and Character Formation: An Indonesian Context," Journal of Interdisciplinary Studies, 26 (1/2): 7394.

MacIntyre, A. 1984. After Virtue. $2^{\text {nd }}$ Edition.Nortre dame, Indiana: University of Nortre Dame Press.

Masrukhan, A. 2016. "Pelaksanaan Pendidikan Karakter Peduli Sosial Di SD Negeri Kotagede 5 Yogyakarta." Skripsi. Program Studi Pendidikan Guru Sekolah Dasar Jurusan Pendidikan Sekolah Dasar, Fakultas Ilmu Pendidikan, Universitas Negeri Yogyakarta.
Nuhamara, D. 2018. "Pengutamaan Dimensi Karakter Dalam Pendidikan Agama Kristen," Jurnal Jaffray, 16 (1): 93-115.

Pazmino, Robert W. 2008. "Curricular Foundations." Foundational Issues in Christian Education. Grand Rapids, Michigan: Baker Academic.

Pemernitah Republik Indonesia. 2010. Kebijakan Nasional Pembangunan Karakter Bangsa Tahun 2010-2025.

Peraturan Pemerintah R.I Nomor 17 Tahun 2010 Tentang Pengelolaan dan Penyelanggaraan Pendidikan.

Peraturan Presiden Republik Indonesia, Nomor 87 Tahun 2017 Tentang Penguatan Pendidikan Karakter.

Peraturan Menteri Pendidikan dan Kebudayaan Republik Indonesia Nomor 20 Tahun 2018 Tentang Penguatan Pendidikan Karakter Pada Satuan Pendidikan Formal.

Rae, Scott B. 2009. Moral Choices: An Introduction to Ethics. Grand Rapids, Michigan: Zondervan.

Rifai, "Pendidikan Kristen Dalam Membangun Karakter Remaja Di Sekolah Menengah,” studylibid.com/doc/846481/pendidikan-kristendalam-membangun-karakter, 1-17. Diunduh 25 September 2018, pkl. 09.39 wib.

Ronance, Mark dan Patrick Gray (Editor). 2007. Teaching The Bible Through Popular Culture and The Arts. Atlanta: Society of Biblical Literature.

Rukiyati, Y. Ch., Nany Suhartini, \& P. Priyoyuwono. 2014. "Penanaman Nilai Karakter Tanggung jawab dan Kerjasama Terintegrasi Dalam Perkuliahan Ilmu Pendidikan." Jurnal Pendidikan Karakter, IV (2): 213-224.

Salaikah, N. 2014. "Konstruksi Pendidikan Karakter Cinta Damai Dalam Film di Timur Matahari (Analisis Semiotik dalam Perspektif PPKn). Naskah Publikasi Karya Ilmiah. Fakultas Ke- 
guruan dan Ilmu Pendidikan Universitas Muhammadiyah, Surakarta.

Sanjaya, W. 2008. Kurikulum dan Pembelajaran. Jakarta: Kencana Perdana Media Group.

Tim Pengembangan MKDP Kurikulum dan Pembelajaran. 2011. Kurikulum \& Pembelajaran. Jurusan Kurikulum dan Teknologi Pendidikan Fakultas Ilmu Pendidikan Universitas Pendidikan Indonesia.

Sattriawan, A. \& Sugeng Sutiarso. 2017. Prosiding Seminar Nasional Matematika dan Pendidikan Matematika 2017, UIN Raden Intan Lampung, 6 Mei 2017, 191-196. https:// ejournal.radenintan.ac.id/index.php/pspm/art icle/download/1034/866. Diunduh 01 November 2018, pkl. 08.02 wib.

Sifa, L. 2015. "Implementasi Karakter Bersahabat dan Peduli Sosial Pada Siswa SMP (Studi Kasus Pada Kegiatan Esktrakurikuler Tari di SMP Negeri 1 Kalinyamatan Kabupaten Jepara Tahun Pelajaran 2014/2015). Naskah Publikasi. Fakultas Keguruan Dan Ilmu Pendidikan Universitas Muhammadiyah Surakarta.

Sidjabat, B.S. 2011. Membangun Pribadi Unggul. Yogyakarta: Penerbit ANDI.

Sidjabat, B.S. 2012. Membesarkan Anak dengan Kreatif. Yogyakarta: Penerbit ANDI.

Sidjabat, B.S. 2018. Mendidik Warga Gereja Melalui Seri Selamat. Jakarta: BPK Gunung Mulia.

Simorangkir, N. 2013. "Peran Guru Pendidikan Agama Kristen Dalam Pembentukan Karakter Anak Didik Melalui Proses Pembelajaran," Jurnal Saintech, 5 (1), 39-44.

Smith, D.I. \& James K.A. Smith. 2011.Teaching Christian Practices. Grand Rapids, Michigan: William B. Eerdmans Publishing Company.

Sukirman. 2016. Menumbuhkan Karakter Bersahabat Pada Anak. Jakarta: Kementerian Pendidikan dan Kebudayaan.
Suluh Siswa 2. 2013. Pendidikan Agama Kristen: Berbuah Dalam Kristus. Jakarta: BPK Gunung Mulia.

Suluh Siswa 3. 2013. Pendidikan Agama Kristen: Berkarya Dalam Kristus. Jakarta: BPK Gunung Mulia.

Supriyanto, A. \& Amien Wahyudi. 2017. "Skala Karakter Toleransi: Konsep dan Operasional Aspek Kedamaian, Menghargai Perbedaan dan Kesadaran Individu." Jurnal Ilmiah Counselia, 7 (2): 61-70.

Susanti, R. 2013. "Penerapan Pendidikan Karakter di kalangan Mahasiswa," Jurnal Al-Ta'lim, 1 (6): 480-487.

Taufan \& Sapriya. 2018. "Pelembagaan Karakter Toleransi Siswa Melalui Program Pendidikan Berkarakter Purwakarta," Citizenship Jurnal Pancasila dan Kewarganegaraan. 6 (1): 17-29.

Vos, Pieter. 2018. "Learning from exemplars: emulation, character formation and the complexities of ordinary life" Journal of Belief \& Values, 39 (1), 17-28.

Warren, Carol A.B. dan Tracy Xavia Karner. 2015. Discovering Qualitative Methods: Ethnography, Interviews, Documents, and Images. New York: Oxfrod University Press.

Warsiah, Idi. n.d. "Implementasi Nilai Sosial Dalam Pendidikan Karakter Melalui Interaksi Sosial.” https://download.portalgaruda.org/artikel.php?artikel=396708\&val=5247\&title, 1 25.

Wati, Dian Chrisna \& Dikdik Baehaqi Arif. 2017. "Penanaman Nilai-nilai Religius di Sekolah Dasar untuk Penguatan Jiwa Profetik Siswa," Prosiding Konferensi Nasional Kewarganegaraan III, Universitas Ahmad Dahlan, Yoyakarta, 11 November 2017, 60-63.

Wiranto, Budi. 2015. "Pengaruh Karakter Disiplin, Mandiri, dan Kerja keras terhadap Kinerja Para Pengrajin Tembaga di Tumang Desa Kecamatan Cepogo Kabupaten Boyolali," 
Naskah Publikasi Artikel. Fakultas Keguruan dan Ilmu Pendidikan, Universitas Muhammadiyah, Surakarta.

Wisesa, F.C. 2017. "Implementasi Nilai Karakter Jujur Di Sekoleh Bunda Paud Kerinci," Nur El-Islam, 4 (2): 142-165.

Wright, N.T. 2010. After You Believe: Why Christian Character Matters. HarperOne.

Zainuddin, H.M. 2013. "Implementasi Pembentukan Karakter Bersahabat Melalui Model Pembe- lajaran Group Investigation.” Mimbar, 29 (1): 69-76.

Zuhri, A. n.d. "Menumbuhkan Perilaku Gemar Membaca Siswa SMA Di Sekolah Melalui Program Free Voluntary Reading (FVR)," https://journal.unari.ac.id/download_fullpap ers-palim92e6826a942full.pdf. Diunduh 01 November 2018, pkl. 16.45 wib. 